\title{
A STUDY OF CROSS-REACTIVITY IN SERUM SAMPLES FROM DOGS POSITIVE FOR Leishmania sp., Babesia canis AND Ehrlichia canis IN ENZYME-LINKED IMMUNOSORBENT ASSAY AND INDIRECT FLUORESCENT ANTIBODY TEST
}

\author{
TRÍCIA MARIA F. DE SOUSA OLIVEIRA ${ }^{1}$, PATRÍCIA I. FURUTA ${ }^{1}$, DÉBORA DE CARVALHO ${ }^{2}$, \\ ROSANGELA Z. MACHADO ${ }^{3}$
}

\begin{abstract}
OLIVEIRA, T.M.F.DE S.; FURUTA, P.I.; CARVALHO, D. DE; MACHADO, R.Z. A study of cross-reactivity in serum samples from dogs positive for Leishmania sp., Babesia canis and Ehrlichia canis in enzyme-linked immunosorbent assay and indirect fluorescent antibody test. [Estudo da reatividade cruzada em amostras de soro de cães positivos para Leishmania sp., Babesia canis e Ehrlichia canis, pelo ensaio imunoenzimático indireto e pela reação de imunofluorescência indireta.] Revista Brasileira de Parasitologia Veterinária, v. 17, n. 1, p.7-11, 2008. Curso de Pós-Graduação em Medicina Veterinária, Faculdade de Ciências Agrárias e Veterinárias, Universidade Estadual Paulista, Campus de Jaboticabal, Jaboticabal, SP 14884-900, Brasil. E-mail: triciaoliveira@yahoo.com.br

To verify the presence of cross-reaction among leishmaniosis, ehrlichiosis and babesiosis in serological diagnostics used in human visceral leishmaniasis control programs, serum samples from leishmaniasis endemic and non-endemic areas were collected and tested by Indirect Fluorescent Antibody (IFAT) and Enzyme-linked immunosorbent assay (ELISA). All serum samples from endemic areas were positive for Leishmania sp., by ELISA and IFAT, 51\% positive for Babesia canis and 43\% for Ehrlichia canis by IFAT. None of the serum samples from non-endemic areas were positive for Leishmania sp., by IFAT, but $67 \%$ were positive for B. canis and $78 \%$ for E. canis using the same test. When tested by ELISA for Leishmania sp., four samples from non-endemic area were positive. These dogs were then located and no clinical signs, parasites or antibody was detected in new tests for a six month period. Only one of these 4 samples was positive for $B$. canis by IFAT and ELISA and three for E. canis by IFAT. The results of the work suggest a co-infection in the endemic area and no serological cross-reaction among these parasites by IFAT and ELISA.
\end{abstract}

KEY WORDS: Leishmania sp., IFAT, ELISA, Ehrlichia canis, Babesia canis.

\section{RESUMO}

Para verificar a existência de reação cruzada entre leishmaniose visceral, erliquiose e babesiose, nos testes sorológicos utilizados em programas de controle da leishmaniose visceral humana, amostras de soro canino provenientes de áreas endêmicas e não endêmicas para essa enfermidade, foram testadas pela Reação de Imunofluorescência (RIFI) e Ensaio

\footnotetext{
${ }^{1}$ Curso de Pós-Graduação em Medicina Veterinária, Faculdade de Ciências Agrárias e Veterinárias, Universidade Estadual Paulista (FCAV-UnespJaboticabal), Jaboticabal, SP 14884-900. E-mails: triciaoliveira@yahoo.com.br e pfuruta@yahoo.com.br

${ }^{2}$ Curso de Pós-Graduação em Fisiologia, Universidade Federal de São Carlos, São Carlos-SP (UFSCAR). E-mail: deby_bio02@yahoo.com.br

${ }^{3}$ Departamento de Patologia Veterinária, FCAV-Unesp-Jaboticabal, Rodovia Paulo Donato Castellane, Km 5, Jaboticabal, SP 14884-900.E-mail: zacarias@fcav.unesp.br
}

imunoenzimático (ELISA). Todos os soros provenientes de área endêmica foram positivos para Leishmania sp pelo ELISA e RIFI, 51\% para Babesia canis e 43\% para Ehrlichia canis pela RIFI. Pela RIFI, nenhum dos soros provenientes de área não endêmica foi positivo para Leishmania sp, sendo $67 \%$ positivos para B. canis e 78\% para E. canis pelo mesmo teste. Quando testados pelo ELISA para Leishmania sp., quatro soros da área não endêmica foram positivos. Os cães foram localizados e nenhum sinal clínico, parasito ou anticorpo foi detectado em novos exames realizados ao longo de seis meses. Os resultados desse trabalho sugerem portanto, a presença de uma co-infecção entre os três parasitos citados nas áreas endêmicas e não a reação cruzada entre eles, nos testes sorológicos de RIFI e ELISA descritos.

PALAVRAS-CHAVE: Leishmania sp., RIFI, ELISA, Ehrlichia canis, Babesia canis. 


\section{INTRODUCTION}

Visceral leishmaniasis is a very important zoonotic disease in South America, mainly in Brazil, where it is caused by Leishmania (Leishmania) chagasi and its vector is Lutzomyia longipalpis sand flies (ARIAS, 1996). Although described as a savage disease, currently the incidence of visceral leishmaniasis in Brazil has increased in urban areas (SANTA ROSA; OLIVEIRA, 1997). In the past ten years, Brazil had a mean of 3.156 human cases/year, with an incidence of two cases/100.000 habitants (BRASIL, 2006).

Domestic dogs (Canis familiaris) are reservoir hosts of zoonotic visceral leishmaniasis, and control of canine leishmaniasis is imperative to reduce the amount of parasites available to sand flies, therefore reducing the human incidence of the disease. Despite evidence from experimental studies showing a decreased incidence of visceral leishmaniasis in both dogs and children following serological screening of dogs and killing of sero-positive animals, the efficiency and acceptability of this control strategy is increasingly being debated. Treating infected dogs is not an effective control strategy as relapses are frequent and dogs regain infectivity weeks after treatment, despite being clinically cured (CHAPPUIS et al., 2007). In Brazil, dog treatment is not recommended, since it can reduce clinical signs, but not the sand fly infection (BRASIL, 2006).

As a result, many serological tests were developed to diagnose canine visceral leishmaniasis. Serological tests are very sensitive and specific, but these tests are generally limited by antibody detection limits and cross-reactivity (FERRER et al., 1995). Indirect fluorescent antibody test (IFAT) has been the most common serological test used for the diagnosis of leishmaniasis, but it is not readily adaptable for large scale seroepidemiological studies. Conversely, enzyme-linked immunosorbent assay (ELISA) has been proven to be at least as sensitive and specific as immunofluorescence and is suitable for large-scale studies (BARBOSA de DEUS et al., 2002).

Ehrlichiosis and Babesiosis are tick-borne diseases, which are very common in Brazil. Babesiosis is a hemolytic disease caused by intraerythrocitic parasites, Babesia canis (LOBETTI, 1998) and Ehrlichia canis is an obligate intracytoplasmatic rickettsia that replicates in the lymph nodes inside mononuclear macrophages, such as Leishmania (Leishmania) infantum (GUILLÉN LLERA et al., 2002). Recently, the Rhipicephalus sanguineus tick, the vector of these two parasites, was experimentally pointed out as being a feasible source of $L$. chagasi infection in dogs (COUTINHO et al., 2005).

Clinical and hematological signs of these three diseases are similar, and serology could be essential for differential diagnosis. Some researches have reported that antibodies against $E$. canis and B. canis are cross-reactive to Leishmania sp. in common serological tests used to detect dogs infected by Leishmania sp. (MANCIANTI et al., 1996; GOMES; CORDEIRO, 2004). To try to elucidate this question, this work studied a possible serological cross-reaction between antibodies against these three parasites, in the serological tests used in leishmaniasis control programs in Brazil.

\section{MATERIAL AND METHODS}

Leishmania sp. maintenance: A Leishmania sp. strain isolated in Araçatuba, São Paulo, Brazil, characterized as complex Donovani, probably L. chagasi, using molecular techniques described by Cortes et al. (2004), was used in this study. The parasites were maintained on a RPMI-1640 medium at $25^{\circ} \mathrm{C}$ and were used to prepare the crude antigens for IFAT and ELISA.

Serum samples: Positive Babesia canis reference sera $(n=2)$ were obtained from dogs experimentally infected with $B$. canis vogeli (FURUTA, 2004) and E. canis reference sera $(n=8)$ were obtained from dogs experimentally infected by $E$. canis (CASTRO et al., 2004). Before experimental infection, these dogs were tested for toxoplasmosis, neosporosis, brucellosis, leptospirosis, babesiosis and ehrlichiosis, being negative for all the diseases cited. In this work, they were tested for leishmaniasis.

The positive Leishmania sp. reference group ( $n=62)$ were from Belo Horizonte, Minas Gerais, Brazil.

Serum samples used as negative reference for the three groups $(n=15)$ were obtained from puppies, in the city of Jaboticabal, São Paulo, Brazil, a non-endemic area for leishmaniasis. The 260 sera used to investigate the existence of leishmaniasis and cross-reactivity among antibodies against leishmaniasis, babesiosis and ehrlichiosis, were obtained from dogs at a rabies vaccination campaign in Jaboticabal, São Paulo, Brazil.

Indirect Immunofluorescent Antibody Test procedure (IFAT) for Leishmania sp.: For antigen preparation, promastigotes of Leishmania sp. were washed tree times in PBS with 1\% BSA and resuspended in PBS-buffered formalin for 30 minutes. The parasites were washed three times again in PBS 1\% BSA, and the pellet was resuspended in PBS so that $10 \mu$ l yielded 20 to 25 parasites per microscope field (400X). Slides with twelve previously marked circles were supplied with $10 \mu \mathrm{l}$ for each circle and then frozen at $-20^{\circ} \mathrm{C}$ until use. Slides with promastigotes forms of the parasite were stabilized at room temperature for the IFAT procedure. Doubling serum dilutions were used, starting at 1:40. The samples were placed over the antigen in the slides and incubated in a moist chamber at $37^{\circ} \mathrm{C}$ for 30 minutes. The slides were washed three times in PBS, and incubated with anti-dog IgG serum conjugated for fluorescein isothiocyanate (KPL, USA) diluted at 1:30 in PBS containing 1mg\% of Evan's Blue. Slides were washed again in PBS, covered with buffered glycerin and a cover slip, and then examined on a fluorescent microscope. In all the experiments, reference sera were included as negative and positive controls. For positive serum samples, parasites displayed a bright-green peripheral stain with a dull fluorescence of the cytoplasm and were considered positive serum samples positive at 1:40 or more.

IFAT for Babesia canis and Ehrlichia canis: The IFAT for 
B. canis was described by Furuta (2004), and serum samples were considered positive at 1:40 or more. The IFAT for $E$. canis was described by the manufacturer of the Kit (VMRD, Inc., USA) and serum samples were considered positive diluted at $1: 20$.

ELISA procedure: The ELISA method used was essentially described by Machado et al. (1997) for B. bovis, with modifications. Briefly, $100 \mathrm{~mL}$ of crude Leishmania sp. antigen diluted in a sodium bicarbonate-carbonated $0.05 \mathrm{M}$ buffer $(\mathrm{pH}$ 9.6) was added per well to an ELISA plate (Nunclon ${ }^{\mathrm{TM}}$ surface; Nunc, Denmark) and $5 \mathrm{mg} \mathrm{mL}$ protein concentration was used. After overnight incubation at $4^{\circ} \mathrm{C}$, plates were washed three times with PBS Tween-20 at $0.05 \%$. The plates were blocked with $200 \mathrm{~mL}$ containing $6 \%$ skim milk for 2 hours at $37^{\circ} \mathrm{C}$, to reduce non-specific binding. The blocking agent was removed, and individual dog serum diluted (1:400) in PBS Tween-20 with 5\% skim milk added to each well and then incubated for 90 minutes at $37^{\circ} \mathrm{C}$, and washed as described above. One hundred $\mathrm{mL}$ of alkaline phosphatase conjugated anti-dog IgG (Sigma Chemical Co) diluted at 1: 4.000 in PBS Tween-20 with $5 \%$ normal rabbit serum was added to each well and then incubated for 90 minutes at $37^{\circ} \mathrm{C}$. The plates were washed and the substrate (p-nitrophenyl phosphate) diluted in dietanolamine buffer, $\mathrm{pH}$ 9.8, was added. Absorbance at 405 $\mathrm{nm}$ was read after 45 minutes incubation at room temperature using an ELISA reader (Dynex Technologies, USA).

Optimal dilutions of antigen and positive and negative sera were determined by checkboard titrations (MACHADO et al., 1997). The immunological reactivity of each serum was calculated using the following equation:

$$
\mathrm{S} / \mathrm{P}=\frac{\text { Mean sample absorbance - Mean absorbance of negative serum reference }}{\text { Mean absorbance of positive - Mean absorbance of negative }}
$$

$\mathrm{S} / \mathrm{P}$ values were grouped into ELISA levels (EL), which ranged from 0 (lowest level) to 9 (highest level), as described by Machado et al. (1997). The discriminating absorbance value (cut-off) was determined as being two and a half times the mean absorbance value of the negative group, where readings above the cut-off value were considered positive.

\section{RESULTS}

The average absorbance of negative sera in ELISA, was $0.120 \pm 0.008$, resulting in a cut-off value of $0.302(E L=3)$. The mean absorbance value of the anti-Leishmania sp positive serum group ( $2.270 \pm 0.428)$ was approximately 22 times greater than the one obtained with negative reference samples, clearly discriminating between the mean absorbances of the negative and positive reference sera. This data gave a sensitivity and specificity of $100 \%$ in the ELISA test described in this work. All serum samples from Belo Horizonte, Minas Gerais, Brazil (positive reference samples) were positive for Leishmania sp. in IFAT. The titers in the IFAT from the 62 positive samples ranged from 1:80 to 1:5.120 and the ELISA

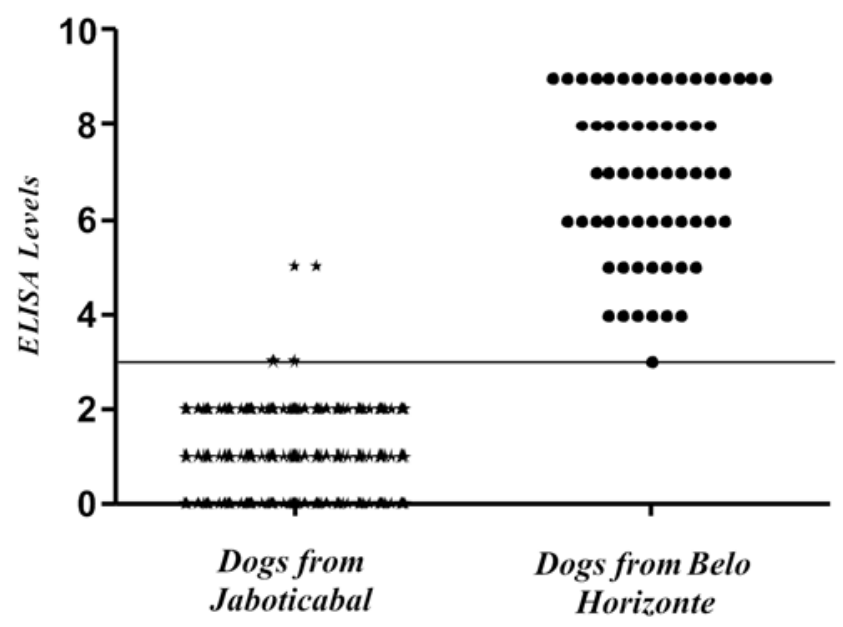

Figure 1. Number of sera from dogs $(n=260)$ from Jaboticabal, São Paulo, Brazil, and Belo Horizonte $(n=62)$, Minas Gerais, Brazil screened by ELISA against Leishmania sp crude soluble antigen plotted by ELISA level (EL).

levels (EL) from these serum samples were concentrated in 6 , 7, 8 and 9 (Figure 1). In the same group, 51\% of sera samples were positive for $B$. canis and $43 \%$ for $E$. canis by IFAT.

Positive reference sera for $E$. canis and B. canis were negative for Leishmania sp. by IFAT and ELISA.

By IFAT, none of the 260 canine serum samples from Jaboticabal, were positive for Leishmania sp., but $67 \%$ $(\mathrm{n}=176)$ were positive for $B$. canis and $78 \%(\mathrm{n}=204)$ for $E$. canis. When tested by ELISA, four of the 260 Jaboticabal sera samples were positive for Leishmania sp., in EL nearly to the cut-off point of the test (Figure 1). These dogs were localized, and bone marrow and lymph nodes were collected for direct detection of the parasite. No clinical signs, parasite or antibodies were detected in new exams carried out on these dogs over a six month period. Only a sample of these four Leishmania sp. positive in ELISA was positive for B. canis by IFAT and three for $E$. canis by IFAT.

\section{DISCUSSION}

Serological results obtained by the samples from Jaboticabal were expected, since the city is endemic for canine ehrlichiosis and babesiosis, but not for leishmaniasis (FURUTA, 2004; NAKAGHI et al., 2004).

Some researches have related a low specificity in serological tests done with crude antigens, especially the ELISA test (CARVALHO et al., 2002; SALOTRA, 2002), but this work had a fine distinction between negative and positive serum samples tested by the Leishmania sp. ELISA standardized. According to Sundar and Rai (2002), antigenic preparations deriving from a cell culture free of cell or protein contaminants, like the culture used in this work, increases specificity of the immunoenzymatic assays.

Due to the fact that there are a large number of somatic antigens described and an unknown number of surface proteins in the crude preparations of Leishmania sp., and as these 
antigens are heterogeneous, the cross reaction with other parasite antigens was suggested (BARBOSA de DEUS et al., 2002). All of the 260 samples from Jaboticabal analysed, were negative for Leishmania sp. by IFAT and only four were positives by the ELISA test. But, 176 were positive for $B$. canis and 204 positives for E. canis. With these results, the possibility of cross-reaction among antibodies against the three diseases related was rejected. The cross-reaction to visceral leishmaniasis with B. canis in an infected dog was observed by dot-ELISA (MANCIANTI et al., 1996) and with dogs infected by B. canis and Ehrlichia spp. by IFAT and ELISA (GOMES; CORDEIRO, 2004). On the other hand, similar to this work, Guillén Llera et al. (2002) have demonstrated the absence of cross-reaction between $E$. canis and $L$. $(L$.) infantum by IFAT in Spain and Martinkovic and Marinculie (2006), the absence of cross-reaction between $B$. canis and $L$. infantum in Croatia.

Jaboticabal is until now considered non-endemic for visceral leishmaniasis. Though, the study of cross-reaction between $E$. canis and $B$. canis with visceral leishmaniasis became more feasibility, since antibodies against Leishmania sp. in dogs from Jaboticabal are not expected. The four dogs, with reaction to Leishmania sp. in the first ELISA in EL nearly to the cut-off point, which suggests a repetition of the test and the performance of other tests to confirm positivity, were retested by the same assay and IFAT, turning out to be negative. None of these dogs had clinical signs or positive parasitological isolation.

Belo Horizonte is an endemic area for the three related diseases (RIBEIRO et al., 1990; SILVA et al., 2001; MOREIRA et al., 2002) and we observed $51 \%(\mathrm{n}=32)$ positive serum for $B$. canis and $43 \%(n=27)$ positive samples for $E$. canis in the 62 Leishmania sp. positive reference sera. In conclusion, the results observed showed the presence of antibodies against the three diseases in the same dogs and no serological cross-reaction among these parasites antibodies.

Acknowledgments:- To Faculdade de Odontologia de Araçatuba, Universidade Estadual Paulista, São Paulo, Brasil, for the Leishmania sp. strain and to Dr. Reginaldo Peçanha Brazil from Centro de Pesquisas René Rachou/FIOCRUZ, Belo Horizonte, Minas Gerais, Brasil, for the Leishmania sp. positive serum samples.

\section{REFERENCES}

ARIAS, J. Epidemiología y control de la leishmaniasis en la Américas, por país o territorio. Washington: Organización Panamericana de la Salud (OPAS), 1996. 52p. (Cuaderno Técnico, 44).

BARBOSA-de-DEUS, R.; MARES-GUIA, M.L.; NUNES, A.Z.; COSTA, K.M.; JUNQUEIRA, R.G.; MAYRINK, W., GENARO, O.; TAVARES, C.A.P. Leishmania major-like antigen for specific and sensitiveserodiagnosis of human and canine visceral leishmaniasis. Clinical and Diagnostic Laboratory Immunology, v. 9, n. 5, p.1361-1366, 2002.
CASTRO, M.B.; MACHADO, R.Z.; AQUINO, L.P.C.T.; ALESSI, A.C.; COSTA, M.T. Experimental, acute canine monocytic ehrlichiosis: clinicopathological and immunopathological findings. Veterinary Parasitology, v. 119, n. 1, p.73-86, 2004.

BRASIL. Ministério da Saúde. Manual de vigilância e controle da leishmaniose visceral. Brasília: MS, 2006, 120p.

CARVALHO, F.A.A; CHAREST, H.; TAVARES, C.A.P.; MATLASHEWSKI, G.; VALENTE, E.P.; RABELLO, A.; GAZZINELLI, R.T.; FERNANDES, A.P. Diagnosis of american visceral leishmaniasis in humans and dogs using the recombinant Leishmania donovani A2 antigen. Diagnostic Microbiology and Infectious Disease, v. 43, n. 4, p.289-295, 2002.

CHAPPUIS, F.; SUNDAR, S.; HAILU, A.; GHALIB H.; RIJAL, S.; PEELING, R.W.; ALVAR, J., BOELAERT, M. Visceral leishmaniasis: What are the needs for diagnosis, treatment and control? Nature Reviews Microbiology, v. 5, n. 11, p. 873-882, 2007.

CORTES, S.; ROLÃO, N.; RAMADA, J.; CAMPINO, L. PCR as a rapid and sensitive tool in the diagnosis of human and canine leishmaniasis using Leishmania donovani s.l.specific kinetoplastid primers. Transactions of the Royal Society of Tropical Medicine and Hygiene, v. 98, n. 1, p.1217, 2004.

COUTINHO, M.T.Z.; BUENO, L.L.; STERZIK, A.; FUJIWARA, R.T.; BOTELHO, J.R.; MARIA, M.; GENARO, O.; LINARDI, P.M. Participation of Rhipicephalus sanguineus (Acari: Ixodidae) in the epidemiology of canine visceral leishmaniasis. Veterinary Parasitology, v. 128, n. 1, p.149-155, 2005.

FERRER, L.; AISA, M.J.; ROURA, X.; PORTÚS, M. Serological diagnosis and treatment of canine leishmaniasis. Veterinary Record, v.136, n.20, p.514-516, 1995.

FURUTA, P. I. Avaliação comparativa entre o Ensaio Imunoenzimático indireto (ELISA) e a Reação de Imunofluorescência Indireta (RFI) para a detecção de anticorpos da classe Ig G em cães naturalmente infectados com Babesia canis. 2004. 48f. Dissertação (Mestrado)-Universidade Estadual Paulista, Jaboticabal, 2004.

GOMES, A.P.S.; CORDEIRO, R.L.R. Reação cruzada no diagnóstico sorológico de leishmaniose canina. Revista Brasileira de Parasitologia Veterinária, v. 23, Supl. 1, p. 238, 2004.

GUILLÉN LLERA, J.L; GARCÍA, M.L.L.; MARTIN REINOSO, E.; DE VIVAR GONZÁLEZ, R. Differential serological testing by simultaneus indirect immunofluorescent antibody test in canine leishmaniosis and erlichiosis. Veterinary Parasitology, v. 109, n. 3, p.185190, 2002.

LOBETTI, R.G. Canine Babesiosis. Compendium on Continuing Education for the Practicing Veterinarian, v.20, n.4, p.418-430, 1998.

MACHADO, R.Z.; MONTASSIER, H.J.; PINTO, A.A. ; LEMOS, E.G.; MACHADO, M.R.F.; VALADÃO, I.F.F.; 
BARCI, L.G.; MALHEIROS, E.B. An enzyme-linked immunosorbent assay (ELISA) for the detection of antibodies against Babesia bovis in cattle. Veterinary Parasitology, v. 71, n. 1, p.17-26, 1997.

MANCIANTI, F.; PEDONESE, F.; POLI, A. Evaluation of dot enzyme-linked immunosorbent assay (dot-ELISA) for the serodiagnosis of canine leishmaniosis as compared with indirect immunofluorescence assay. Veterinary Parasitology, v. 65, n. 1, p.1-9,1996.

MARTINKOVIC, F.; MARINCULIE, A. Antibodies against Leishmania cross-react with Crithidia luciliae: indirect immunofluorescence and Dot- ELISA study in dogs. Parasitology Research, v. 98, n. 4, p. 378-380, 2006.

MOREIRA, S.M.; BASTOS, C.V.; SANTOS, M.; PASSOS, L.M.F.; ARAÚJO, R.B. Estudo retrospectivo (1998-2001) da erliquiose canina em Belo Horizonte, Minas Gerais, Brasil. In: CONGRESSO BRASILEIRO DE PARASITOLOGIA VETERINÁRIA, 12, 2002, Rio de Janeiro. Anais... Rio de Janeiro: CBPV, 2002. 1 CD-ROM.

NAKAGHI, A.C.H. ; MACHADO, R.Z.; TINUCCI-COSTA, M.; ANDRÉ, M.R.; BALDANI, C.D.; ANDRADE, G.M. Deteç̧ão molecular de Ehrlichia canis pela nested PCR e avaliação de sua sensibilidade no diagnóstico da erliquiose canina. Revista Brasileira de Parasitologia Veterinária, v. 23, Supl. 1, p.356, 2004.

RIBEIRO, M.F.B.; LIMA, J.D.; PASSOS, L.M.F.; GUIMARÃES, A.M. Freqüência de anticorpos fluorescentes anti Babesia canis em cães de Belo Horizonte, Minas Gerais. Arquivos Brasileiros de Medicina Veterinária e Zootecnia, v.42, n.6, p.511-517,1990.

SALOTRA, P.; SREENIVAS, G.; NASIM, A.A.; SUBBARAJU, B.V.; RAMESH, V. Evaluation of enzyme-linked immunosorbent assay for diagnosis of post-kala-azar dermal leishmaniasis with crude or recombinant k39 antigen. Clinical and Diagnostic Laboratory Immunology, v. 9, n. 2, p. 370-373, 2002.

SANTA ROSA, A. C.I.; OLIVEIRA, S.C.I. Leishmaniose visceral: breve revisão sobre uma zoonose reemergente. Clínica Veterinária, v. 2, n. 11, p.24-28, 1997.

SILVA, E.S.; GONTIJO, C.M.F.; PACHECO, R.S.; FIUZA, V.O.P.; BRAZIL, R.P.Visceral leishmaniasis in the metropolitan region of Belo Horizonte, state of Minas Gerais, Brazil. Memórias do Instituto Oswaldo Cruz, v. 96, n. 3, p.285-291, 2001.

SUNDAR, R.; RAI, M. Laboratory diagnosis of visceral leishmaniasis. Clinical and Diagnostic Laboratory Immunology, v. 9, n. 5, p.951-958, 2002.

Received on June 26, 2006.

Accepted for publication on March 28, 2008. 